\title{
PERENCANAAN SISTEM PLAMBING DAN HIDRAN KEBAKARAN PADA PROYEK PEMBANGUNAN HOTEL PESONA ALAM
}

\author{
Ivana Patricia Lilipaly'), Ririn Endah Badriani' ${ }^{1}$, dan Yeny Dhokhikah') \\ 1) Jurusan Teknik Sipil, Universitas Jember, Jember, Jawa Timur \\ ivanaplilipaly@gmail.com
}

\begin{abstract}
Pesona Alam Hotel is one of the hotels located in the Cisarua area, Bogor. An adequate plumbing system and fire hydrant system planning are needed to support the Comfort and safety of hotel visitor activities. The Plumbing Tool Load Unit Method is used in determining the dimensions of both clean and wastewater. Isometric depiction of piping networks and determining the diameter of clean water pipes is assisted by Pipe Flow Expert software. Based on the calculation, it is found that the need for clean water per day at Pesona Alam Hotel is $230 \mathrm{~m}^{3} /$ day with the required diameter of clean water pipes of 0.5", 0.75", 1", 1.25", and 2". The estimated wastewater produced is $207 \mathrm{~m}^{3} /$ day with a diameter of 1.25", 1.5", 2", 2.5", 3" and 4" wastewater. Whereas for the fire hydrant system, 3 types of fire hydrants are used, namely the pillar hydrant, fire hose reel, and sprinkler. The need for clean water for fire fighting is $270 \mathrm{~m}^{3}$.
\end{abstract}

Keywords: plumbing, fire hydrant, pipe diameter, clean water requirement

\begin{abstract}
ABSTRAK
Hotel Pesona Alam merupakan salah satu hotel yang terletak di kawasan Cisarua, Bogor. Perencanaan system plambing dan Hidran Kebakaran yang memadai diperlukan untuk menunjang kenyamanan dan keamanan aktivitas pengunjung Hotel. Perhitungan perencanaan air bersih maupun kotor, digunakan metode Unit Beban Alat Plambing. Penggambaran isometri jaringan perpipaan dan penentuan diameter pipa air bersih dibantu dengan software Pipe Flow Expert. Berdasarkan perhitungan, didapatkan kebutuhan air bersih per hari pada Hotel Pesona Alam adalah $230 \mathrm{~m}^{3} /$ hari dengan diameter pipa air bersih yang diperlukan sebesar 0.5”, 0.75", 1", 1.25", dan 2". Perkiraan air buangan yang dihasilkan sebesar $207 \mathrm{~m}^{3} /$ hari dengan diameter air buangan yang digunakan sebesar 1.25", 1.5", 2", 2.5", 3" dan 4". Sedangkan untuk sistem hidran kebakaran digunakan 3 jenis hidran kebakaran yaitu pillar hydrant, fire hose reel, dan sprinkler. Kebutuhan air bersih untuk pemadam kebakaran sebesar $270 \mathrm{~m}^{3}$.
\end{abstract}

Kata kunci: plambing, hidran kebakaran, diameter pipa, kebutuhan air bersih 


\section{PENDAHULUAN}

Hotel Pesona Alam merupakan bangunan Hotel yang terletak di daerah Cisarua, Bogor. Bangunan Hotel Pesona Alam terdiri atas 3 blok tower yang menyatu dengan masing-masing Tower berjumlah 4 lantai. Perencanaan saluran air bersih yang optimal pada Hotel Pesona Alam sangat diperlukan agar air bersih dapat tersalurkan dengan baik keseluruh bagian Hotel. Sistem plambing untuk air buangan juga perlu dirancang dengan baik agar tidak merusak bagian pipa yang dilalui sehingga mengganggu sanitasi lingkungan. Beberapa hal yang perlu diperhatikan dalam perencanaan sistem plambing yaitu: laju aliran pipa, kecepatan aliran dalam pipa, diameter pipa, serta tekanan air dalam pipa dan digunakan software pipe flow expert dalam penggambaran serta analisis jaringan perpipaan. Perencanaan sistem proteksi kebakaran baik didalam maupun diluar gedung juga perlu dilakukan secara optimal sehingga kerugian akibat terjadinya kebakaran dapat dikurangi. Tujuan dari penelitian ini adalah menentukan sistem perpipaan pada sistem air bersih dan air buangan serta menentukan sistem pemadam kebakaran yang baik pada Hotel Pesona Alam.

\section{KAJIAN PUSTAKA}

\subsection{Sistem Penyediaan Air Bersih}

Menurut Morimura \& Noerbambang (1993), sistem penyediaan air bersih dikelompokkan menjadi beberapa jenis, yaitu sistem sambungan langsung, sistem tangki atap, dan sistem tangka tekan. Pada perencanaan Hotel Pesona Alam digunakan sistem tangki atap.

Sistem tangki atap bekerja dengan menampung terlebih dahulu air yang akan disalurkan dalam reservoir bawah yang berada dibawah muka tanah tidak jauh dari bangunan untuk dipompakan menuju tangki atas yang telah terinstalasi di lantai teratas bangunan.

\subsubsection{Perhitungan Kapasitas Tangki Air}

Perhitungan Kapasitas Tangki air disesuaikan dengan metode yang tertera pada buku Perencanaan dan Pemeliharaan system Plambing (Noerbambang \& Morimura, 1993). Perhitungan kapasitas tangka air mencakup kapasitas tangka air bawah dan kapasitas tangka air atas.

1. Kapasitas tangki air bawah

Tangki bawah untuk bangunan gedung sebaiknya diletakkan diatas tanah dengan ketinggian antara 45 hingga $60 \mathrm{~cm}$. Rumus penghubung antara kapasitas tangki bawah dengan kapasitas pipa dinas:

$$
\mathrm{Q}_{\mathrm{d}}=\mathrm{Q}_{\mathrm{s}} \cdot \mathrm{T}
$$


dengan:

$\mathrm{Q}_{\mathrm{d}}=$ jumlah kebutuhan air per hari $\left(\mathrm{m}^{3} /\right.$ hari)

$\mathrm{Q}_{\mathrm{s}}=$ kapasitas pipa dinas $\left(\mathrm{m}^{3} / \mathrm{jam}\right)$

$\mathrm{T}=$ rata-rata pemakaian sehari (jam/hari)

Kapasitas tangki air yang digunakan dapat dihitung dengan rumus:

$\mathrm{V}_{\mathrm{R}}=\mathrm{Q}_{\mathrm{d}}-\mathrm{Q}_{\mathrm{s}} \mathrm{T}$

dengan:

$\mathrm{V}_{\mathrm{R}}=$ volume tangki air minum $\left(\mathrm{m}^{3}\right)$

2. Kapasitas tangki atap

Kapasitas tangki atap dapat dihitung menggunakan rumus:

$\mathrm{V}_{\mathrm{E}}=\left(\mathrm{Q}_{\mathrm{p}}-\mathrm{Q}_{\max }\right) \mathrm{T}_{\mathrm{p}}-\mathrm{Q}_{\mathrm{pu}} \times \mathrm{T}_{\mathrm{pu}}$

dengan:

$\mathrm{V}_{\mathrm{E}}=$ kapasitas tangki atas (liter)

$\mathrm{Q}_{\mathrm{p}}=$ kebutuhan puncak (liter/menit)

$\mathrm{Q}_{\max }=$ kebutuhan jam puncak (liter/menit)

$\mathrm{Q}_{\mathrm{pu}}=$ kapasitas $\quad$ pompa pengisi (liter/menit)

$\mathrm{T}_{\mathrm{pu}}=$ jangka waktu kerja pompa pengisi (menit)

\subsubsection{Penentuan laju aliran air}

Laju aliran air ditentukan berdasarkan tabel serta grafik Unit Beban
Alat Plambing (UBAP) yang tercantum pada SNI 03-6481-2000 tentang sistem plambing. Sesudah didapatkan nilai pemakaian serentak sebesar liter/menit sebagai pemakaian maksimum, kebutuhan pemakaian pada jam puncak dapat dihitung dengan persamaan sebagai berikut:

$$
\mathrm{Q}_{\mathrm{h}}=\frac{Q m \max \times 60 \mathrm{menit} / \mathrm{jam}}{C 2}
$$

dengan:

$$
\begin{aligned}
\mathrm{Q}_{\mathrm{h}}= & \text { pemakaian air rata-rata } \\
& \left(\mathrm{m}^{3} / \mathrm{jam}\right) \\
\mathrm{C}_{2}= & \text { konstanta bernilai antara } 3- \\
& 4
\end{aligned}
$$

Untuk mengatasi kebocoran, tambahan air untuk pemanas gedung dan penyiraman tanaman diperlukan penambahan sebesar $20 \%$ pada kebutuhan air total (Qh-total), sehingga:

$$
\mathrm{Q}_{\mathrm{h}-\mathrm{t} \text { tal }}=\mathrm{Q}_{\mathrm{h}}+\mathrm{Q}_{\text {tambahan }}\left(20 \% \mathrm{Q}_{\mathrm{h}}\right)
$$

\subsection{Sistem Air Buangan}

\subsubsection{Sistem pembuangan air}

Berdasarkan SNI 03-7065-2005 sistem pembuangan air terbagi menjadi dua, yaitu:

1. Sistem campuran, yang berarti pembuangan air kotor dan air bekas dikumpulkan dan dialirkan ke dalam satu saluran.

2. Sistem terpisah, yang berarti pembuanganair kotor dan air bekas masing-masing 
dikumpulkan dan dialirkan secara terpisah.

\subsubsection{Kemiringan dan kecepatan aliran pipa air buangan}

Kecepatan aliran terbaik dalam pipa berkisar antara $0.6-1.2 \mathrm{~m} /$ detik dengan ukuran pipa untuk jalur panjang sebaiknya tidak kurang dari $50 \mathrm{~mm}$. Kemiringan pipa pembuangan horizontal untuk diameter kurang dari atau sama dengan $75 \mathrm{~mm}$ dapat menggunakan kemiringan minimum $1 / 50$, sedangkan jika diameter kurang dari atau sama dengan $100 \mathrm{~mm}$ digunakan kemiringan minimum $\quad 1 / 100$ (Noerbambang \& Morimura, 1993).

\subsubsection{Ukuran pipa air buangan}

Berdasarkan SNI 03-7065-2005, pipa pembuangan memiliki beberapa ketentuan sebagai berikut:

1. Ukuran minimum pipa cabang mendatar harus mempunyai ukuran minimal sama dengan diameter terbesar dari perangkap alat plambing yang dilayaninya.

2. Ukuran minimum pipa tegak harus mempunyai ukuran minimal sama dengan diameter terbesar cabang mendatar yang disambungkan ke pipa tegak tersebut.

3. Pengecilan ukuran pipa tidak boleh dalam arah air buangan.
Pengecualian hanya pada kloset, dimana pada lobang keluarnya dengan diameter $100 \mathrm{~mm}$ dipasang pengecilan pipa 100x75 mm.

4. Pipa dibawah tanah adalah pipa pembuangan yang ditanam di dalam tanah atau di bawah lantai dengan ukuran diameter minimal $50 \mathrm{~mm}$

5. Interval cabang adalah jarak pada pipa tegak antara dua titik dimana cabang mendatar disambungkan pada pipa tegak tersebut, jarak minimalnya 2.5 $\mathrm{m}$.

\subsection{Penentuan Ukuran Pipa Ven}

Menurut Morimura \& Noerbambang (1993), beberapa hal umum yang perlu diperhatikan dalam penentuan ukuran pipa ven adalah sebagai berikut:

1. Ukuran pipa ven minimum 32 mm dan tidak boleh kurang dari setengah kali diameter cabang mendatar pipa buangan atau pipa tegak ven yang disambungkannya.

2. Ukuran pipa ven pelepas minimum $32 \mathrm{~mm}$ dan tidak boleh kurang dari setengah kali diameter cabang mendatar pipa pembuangan yang dilayaninya. 
3. Ukuran pipa ven tegak tidak boleh kurang dari ukuran pipa tegak air buangan yang dilayaninya.

4. Ukuran pipa ven pelepas untuk offset pipa pembuangan harus sama dengan atau lebih besar dari pada diameter pipa tegak ven atau pipa tegak air buangan (yang terkecil diantara keduanya)

\subsection{Perencanaan Sistem Hidran Kebakaran}

Berdasarkan SNI 03-1745-2000, tentang tata cara perencanaan dan pemasangan sistem pipa tegak dan slang untuk pencegahan bahaya kebakaran pada bangunan rumah dan gedung, fire hydrant adalah suatu sistem instalasi pemipaan berisi air bertekanan tertentuyang digunakan sebagai sarana untuk memadamkan kebakaran. Terdapat beberapa tipe sistem pemadam kebakaran dalam gedung, yaitu:

1. Fire hose reel, yang merupakan tipe hidran kebakaran yang terdiri dari suatu dan pipa elastis yang ditempatkan pada suatu bak di tembok. Tiap kotak biasanya dilengkapi dengan martil untuk memecahkan kaca penutup kotak saat terjadi kebakaran.

2. Sprinkler, yang merupakan tipe pemadam kebakaran yang terletak pada atap tiap lantai dalam bentuk jarring-jaring. Tiap outlet sprinkler dilengkapi dengan sensor tidak tahan panas atau api sehingga ketika kebakaran terjadi air akan keluar secara otomatis. Ketentuan pemasangan sprinkler tertera pada SNI 03-3989-2000 tentang tata cara perencanaan dan pemasangan sistem sprinkler otomatis untuk pencegahan bahaya kebakaran pada bangunan gedung.

\section{METODE PENELITIAN}

\subsection{Lokasi Penelitian}

Hotel Pesona Alam terletak di Jalan Taman Safari No. 101, Kampung Baru, Cibeureum, Kecamatan Cisarua, Bogor, Jawa Barat. Hotel Pesona Alam terbagi menjadi 3 blok bangunan yang tergabung menjadi 1. Blok A dan B terdiri atas 6 lantai, sedangkan Blok $\mathrm{C}$ terdiri atas 4 lantai dengan antai paling atas menjadi poolside hotel. 


\subsection{Tahapan Penelitian}

Tahapan awal berupa tahapan Persiapan penelitian yaitu survey lokasi, studi literatur, serta pembuatan proposal. Data yang diperlukan dalam penelitian ini adalah data sekunder berupa gambar arsitektur denah tiap lantai Hotel Pesona Alam Bogor. Data didapatkan dari kontraktor Proyek Hotel Pesona Alam.

\subsubsection{Pengolahan data}

Tahapan pengolahan data pada penelitian ini terbagi atas 3 tahapan, yaitu:

1. Sistem air bersih
a. Melakukan desain distribusi air bersih mulai dari tangka bawah ke tangka atas
b. Perhitungan kebutuhan air bersih
c. Perhitungan volume tampungan tangka air bawah dan tangka air atas
d. Penentuan kebutuhan dimensi pipa

2. Sistem air buangan dan ven

a. Melakukan desain penyaluran air buangan ke bak ekualisasi

b. Penentuan kebutuhan dimensi pipa air buangan dan ven

3. Sistem hidran kebakaran a. Perhitungan jumlah alat pemadam kebakaran yang diperlukan

b. Perhitungan kebutuhan air dan kapasitas ground water tank untuk kebakaran

c. Penentuan dimensi pipa

\section{HASIL DAN PEMBAHASAN}

\subsection{Perhitungan Kebutuhan Air Bersih}

Kebutuhan air bersih pada Hotel Pesona Alam ditentukan dengan metode Unit Beban Alat Plambing (UBAP). Untuk mencari nilai total UBAP yang terdapat pada Hotel Pesona Alam, sebelumnya dilakukan perhitungan terlebih dahulu terhadap jumlah kebutuhan alat plambing berdasarkan denah Hotel Pesona Alam. Setelah jumlah alat plambing diketahui, Total UBAP diketahui dengan mengalikan jumlah alat plambing dengan nilai Unit Beban Alat Plambing sesuai dengan jenis alat plambing. Sehingga didapatkan hasil perhitungan sebagai berikut:

\section{Tabel 1. Perhitungan Unit Beban Alat} Plambing

\begin{tabular}{lccc}
\hline \multicolumn{1}{c}{ Alat Plambing } & Jumlah & $\begin{array}{c}\text { UBAP } \\
\text { (SNI) }\end{array}$ & Jumlah \\
\hline Kloset & 174 & 5 & 870 \\
Jet Washer & 174 & 2 & 348 \\
Urinoir & 4 & 5 & 20 \\
Bath Tub & 26 & 2 & 52 \\
Pancuran Mandi & 150 & 2 & 300 \\
Bak Cuci Tangan & 148 & 1 & 148 \\
Bak Cuci Dapur & 4 & 2 & 8 \\
Jumlah & & & 1746 \\
\hline
\end{tabular}


Nilai UBAP yang didapatkan kemudia diplot pada kurva hubungan antara jumlah UBAP dengan laju aliran air sehingga nilai laju aliran air dapat diketahui.

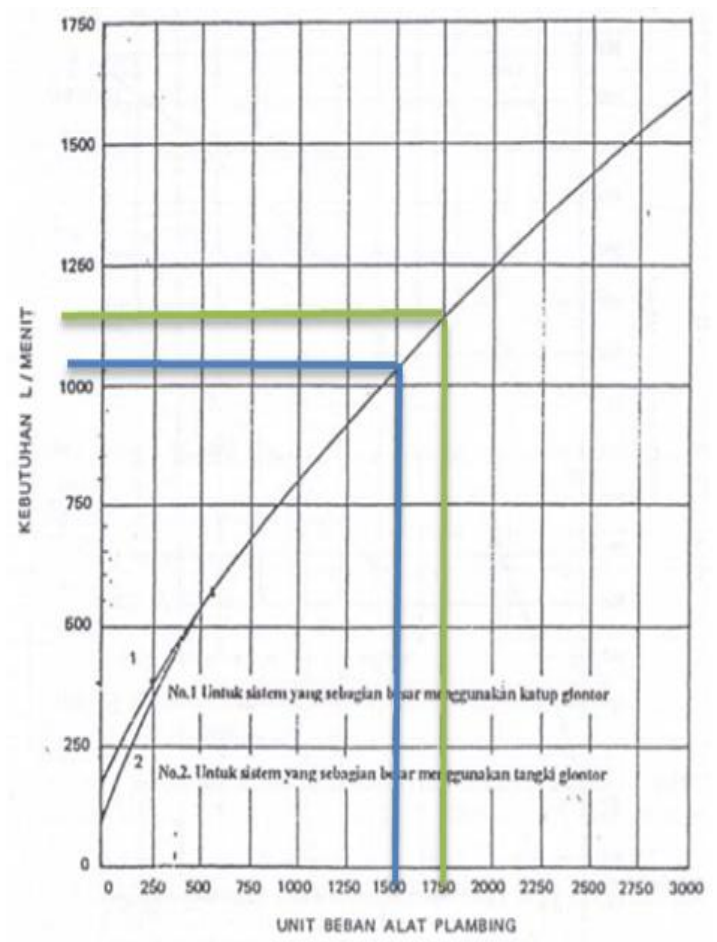

Gambar 1. Hubungan antara Unit Beban Alat Plambing dengan Laju Air untuk UBAP sampai dengan 3000

Berdasarkan hasil interpolasi, nilai laju air maksimum untuk UBAP 1746 adalah sebesar $1.1 \mathrm{~m}^{3} /$ menit. Melalui perhitungan pada persamaan (4), didapatkan kebutuhan air pada jam puncak sebesar $22.97 \mathrm{~m}^{3} / \mathrm{jam}$.

Kebutuhan air rata-rata per hari dapat dihitung dengan mengalikan kebutuhan air pada jam puncak dengan jangka waktu pemakaian air rata-rata sebesar 10 jam. Sehingga didapatkan:

$$
\begin{aligned}
\mathrm{Q}_{\mathrm{d}} & =22.97 \mathrm{~m}^{3} / \mathrm{jam} \times 10 \mathrm{jam} / \mathrm{hari} . \\
& =229.7 \mathrm{~m}^{3} / \text { hari } \approx 230 \mathrm{~m}^{3} / \text { hari. }
\end{aligned}
$$

\subsection{Perhitungan Kapasitas Tangki}

Penyediaan air bersih pada Hotel Pesona Alam menggunakan sistem tangki atap, sehingga air dari Tangki air bawah ditampung terlebih dahulu ditangki atas sebelum didistribusikan ke seluruh alat plambing.

1. Kapasitas tangki air bawah

Berdasarkan perhitungan kebutuhan air bersih didapatkan nilai Qh sebesar $22.97 \mathrm{~m}^{3} / \mathrm{jam}$. Sehingga kapasitas pipa dinas sebesar:

$$
\begin{aligned}
\text { Qs } & =\frac{2}{3} \times 22.97 \mathrm{~m}^{3} / \mathrm{jam} \\
& =15.31 \mathrm{~m}^{3} / \mathrm{jam}
\end{aligned}
$$

Setelah kapasitas pipa dinas didapatkan, volume tangki air bawah dapat diketahui berdasarkan perhitungan persamaan didapatkan nilai volume tangka air bawah $\left(\mathrm{V}_{\mathrm{R}}\right)$ sebesar $76.88 \mathrm{~m}^{3} \approx 80$ $\mathrm{m}^{3}$. Dimensi $8 \mathrm{~m} \times 5 \mathrm{~m} \times 2 \mathrm{~m}$ digunakan untuk tangki air bawah.

2. Kapasitas tangki air atas

Direncanakan 3 buah roof tank untuk mempermudah pendistribusian air bersih pada Hotel Pesona Alam. Sebelum volume tangki atas dapat ditentukan, perlu dilakukan 
perhitungan terhadap kapasitas aliran air $\left(\mathrm{Q}_{\mathrm{pu}}\right)$ dengan:

$$
\begin{aligned}
Q_{p u} & =\frac{Q h}{60} \\
& =\frac{22.97 m 3 / j a m}{60} \\
& =0.38 \mathrm{~m}^{3} / \text { menit }
\end{aligned}
$$

Asumsi, $\mathrm{Tp}=60$ menit dan $\mathrm{TPu}$ $=10$ menit. Didapatkan Volume tangki air atas sebesar:

$$
\mathrm{V}_{\mathrm{RT}}=\left(\mathrm{Q}_{\mathrm{p}}-\mathrm{Q}_{\mathrm{pu}}\right) \times \mathrm{T}_{\mathrm{p}}-\left(\mathrm{Q}_{\mathrm{pu}} \mathrm{x} \mathrm{T}_{\mathrm{pu}}\right)
$$

$=1.1 \mathrm{~m}^{3} /$ menit $-0.38 \mathrm{~m}^{3} /$ menit $) \times 60$ menit- $\left(0.38 \mathrm{~m}^{3} /\right.$ menitx10 menit $)=$ $43.005 \mathrm{~m}^{3} \approx 45 \mathrm{~m}^{3}$

Volume $15 \mathrm{~m}^{3}$ digunakan untuk 1 tangki atas atap dengan dimensi 5 $\mathrm{m} \times 3 \mathrm{~m} \times 1 \mathrm{~m}$.

3. Dimensi pipa air bersih dari Tangki bawah ke Tangki atas

Nilai Kapasitas aliran air $\left(\mathrm{Q}_{\mathrm{pu}}\right)$ yang ada pada pipa sebesar 0.38 $\mathrm{m}^{3} /$ menit $=0.0063 \mathrm{~m}^{3} /$ detik.

Diasumsikan nilai kecepatan maksimum ( $\left.\mathrm{V}_{\text {maks }}\right)$ sebesar $2 \mathrm{~m} /$ detik, maka:

$$
\begin{aligned}
\mathrm{D} & =\sqrt{\frac{4 \times 0.0063 \mathrm{~m} 3 / \text { detik }}{3.14 \times 2 \mathrm{~m} / \text { detik }}} \\
& =0.0637 \mathrm{~m}=63.7 \mathrm{~mm}
\end{aligned}
$$

Digunakan diameter pipa $80 \mathrm{~mm}$ (3.5"). Selanjutnya dilakukan perhitungan kontrol kecepatan untuk mengetahui dimensi pipa yang digunakan memenuhi kecepatan aliran.

$$
\begin{aligned}
\mathrm{V}_{\text {cek }} & =\frac{4 \times Q}{\Pi \times D^{2}} \\
& =\frac{4 \times 0.0063 \mathrm{~m} 3 / \text { detik }}{3.14 \times 0,08^{2}} \\
& =1.27 \mathrm{~m} / \text { detik }
\end{aligned}
$$

Diameter $80 \mathrm{~mm}$ memenuhi standar kecepatan aliran $(0.9 \mathrm{~m} / \mathrm{det}<$ $\mathrm{V}<2 \mathrm{~m} /$ det $)$.

\subsection{Penentuan Diameter pipa air bersih}

Penentuan diameter pipa air bersih yang diperlukan didasarkan pada nilai Unit Beban Alat Plambing sesuai dengan jenis alat plambing seperti tercantum pada SNI 8153 tahun 2015. Sebelum diameter pipa dapat ditentukan, isometri jaringan pipa air bersih pada unit kamar perlu digambar terlebih dahulu. Contoh denah serta isometri pada kamar tipe standart dapat dilihat pada Gambar 2 dan 3.

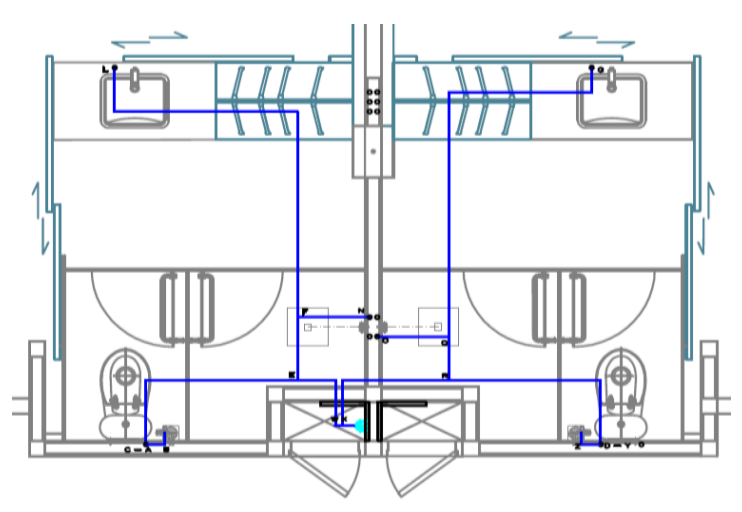

\section{Gambar 2. Denah Kamar Mandi Tipe Kamar Standar}




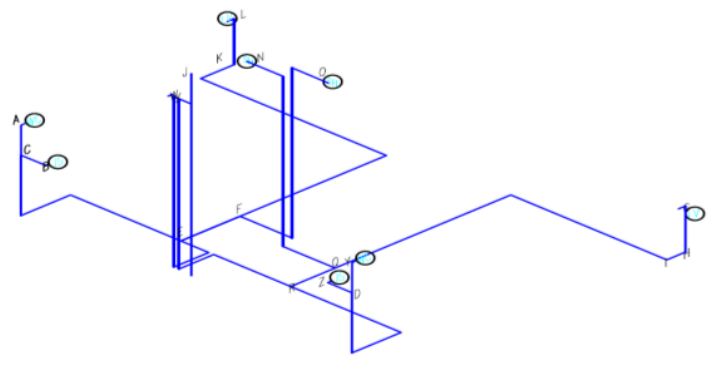

Gambar 3. Isometri Pipa Air Bersih pada Kamar Tipe standar

Sebagai contoh perhitungan untuk alat plambing jenis kloset (jalur C-A) yang memiliki nilai UBAP sebesar 5. Nilai tersebut kemudian diplotkan pada grafik perkiraan beban kebutuhan air sehingga didapatkan nilai laju aliran sebesar 21.54 liter/menit atau sebesar $0.0006 \mathrm{~m}^{3} /$ detik. Diameter untuk kloset didapatkan sebesar:

$$
\begin{aligned}
\mathrm{D} & =\sqrt{\frac{4(0.0006 \mathrm{~m} 3 / \text { detik })}{\Pi(2 \mathrm{~m} / \mathrm{s})}} \\
& =19.6 \mathrm{~mm}
\end{aligned}
$$

Diameter pipa sebesar $20 \mathrm{~mm}$ untuk kloset dengan kecepatan aliran yang dihasilkan sebesar:

$$
\mathrm{V}=\frac{4(0,0006)}{\Pi 0,025^{2}}=1.23 \mathrm{~m} / \mathrm{detik}
$$

Diameter setiap jenis alat plambing dihitung sehingga didapatkan hasil perhitungan seperti pada Tabel 2.

Setelah diameter secara umum didapatkan, isometri diameter pipa air bersih keseluruhan digambarkan dengan menggunakan Software pipe flow expert. Hasil Isometri dapat dilihat pada Gambar 4.
Tabel 2. Diameter Pipa Air Bersih

\begin{tabular}{lcccc}
\hline $\begin{array}{c}\text { Alat } \\
\text { Plambing }\end{array}$ & UBAP & $\begin{array}{c}\text { Laju } \\
\text { Aliran } \\
\text { Airmin }\end{array}$ & $\begin{array}{c}\text { Diameter } \\
\text { hitung } \\
(\mathrm{mm})\end{array}$ & $\begin{array}{c}\text { Diameter } \\
\text { pakai } \\
(\mathrm{mm})\end{array}$ \\
\hline $\begin{array}{l}\text { Kloset } \\
\text { Pancuran }\end{array}$ & 5 & 21.54 & 19.6 & 20 \\
$\begin{array}{l}\text { Mandi } \\
\text { Bak cuci } \\
\text { tangan }\end{array}$ & 2 & 14.27 & 12.3 & 15 \\
$\begin{array}{l}\text { Jet } \\
\text { Washer }\end{array}$ & 2 & 14.27 & 12.3 & 15 \\
\hline
\end{tabular}

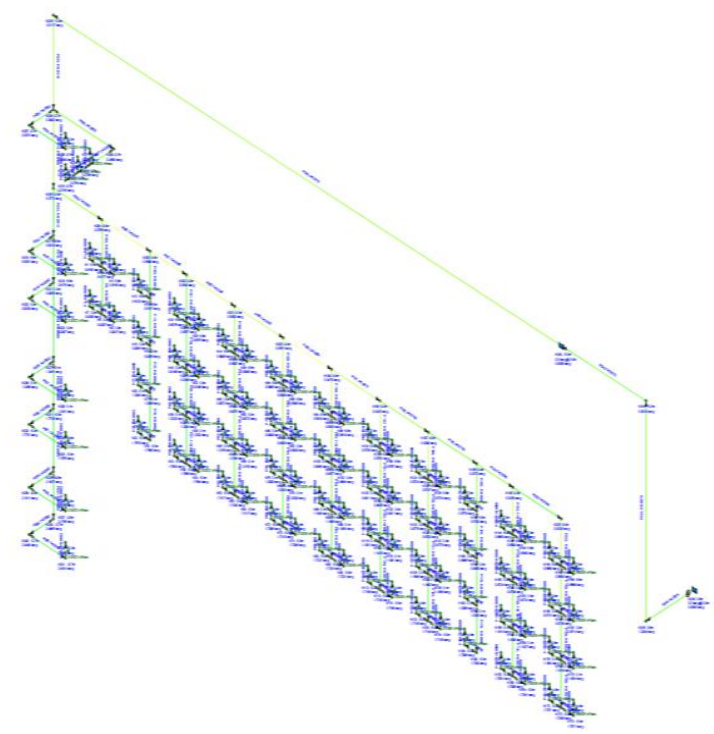

Gambar 4. Isometri Pipa Air Bersih pada Hotel Pesona Alam Blok B

Berdasarkan analisa software didapatkan ukuran pipa tegak $60 \mathrm{~mm}, 80$ $\mathrm{mm}, 100 \mathrm{~mm}$, dan $150 \mathrm{~mm}$ yang aman untuk digunakan dalam penyaluran air ketiap lantainya.

\subsection{Penentuan Diameter pipa air buangan}

Sistem pembuangan air pada Hotel Pesona Alam menggunakan sistem pembuangan terpisah, sehingga pipa air kotor dipisahkan dengan pipa air bekas. Penentuan diameter pipa air buangan juga 
didasarkan dengan metode UBAP.

Sebelum diameter pipa dapat ditentukan, isometri jaringan pipa air kotor maupun bekas digambarkan terlebih dahulu. Contoh isometri air kotor dan bekas pada kamar standart dapat dilihat pada Gambar 5.

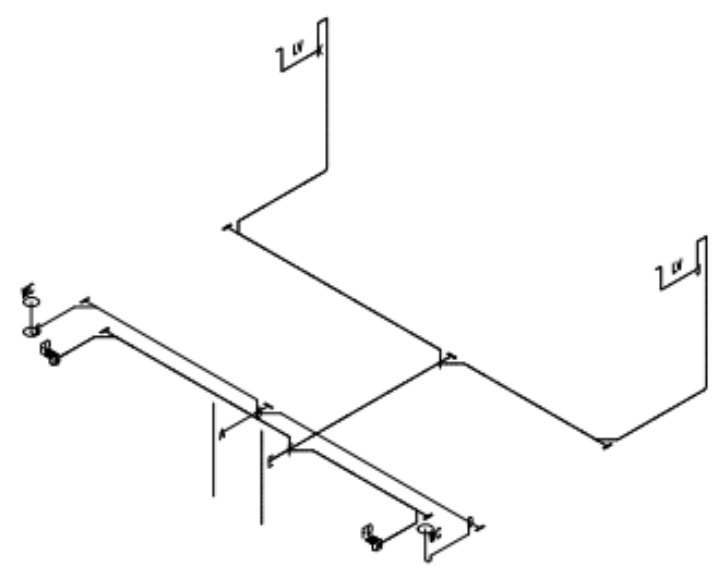

Gambar 5. Isometri Pipa Air Bekas dan Kotor pada Kamar Tipe Standar

Setelah isometri diketahui, ditentukan nilai UBAP air buangan yang bekerja pada setiap bagian pipa berdasarkan jenis alat plambing. Sebagain contoh, untuk alat plambing pengering lantai, nilai UBAP adalah 2, berdasarkan SNI diameter pipa yang digunakan adalah $40 \mathrm{~mm}$, sehingga digunakan diameter 40 $\mathrm{mm}$. Penentuan yang sama berlaku untuk bak cuci tangan dengan UBAP bernilai 1 , sehingga diameter yang dipergunakan adalah $32 \mathrm{~mm}$. Hasil perhitungan diameter seperti terlihat pada Tabel 3.
Tabel 3. Diameter Pipa Air Bekas dan

Kotor

\begin{tabular}{lccc}
\hline $\begin{array}{c}\text { Alat } \\
\text { Plambing }\end{array}$ & UBAP & $\begin{array}{c}\text { Diameter } \\
\text { hitung } \\
(\mathrm{mm})\end{array}$ & $\begin{array}{c}\text { Diameter } \\
\text { pakai } \\
(\mathrm{mm})\end{array}$ \\
\hline Kloset & 4 & 75 & 3 \\
Pengering & 2 & 40 & 1.5 \\
Lantai & 2 & 40 & 1.5 \\
\hline Lavatori & & & \\
\hline
\end{tabular}

Sedangkan, untuk diameter pipa tegak yang digunakan, berdasarkan nilai UBAP perlantai didapatkan nilai $100 \mathrm{~mm}$ seperti tertera pada Tabel 4 .

Tabel 4. Diameter Pipa Tegak Air Bekas dan Kotor Blok A

\begin{tabular}{lcccc}
\hline \multicolumn{1}{c}{ Lantai } & UBAP & $\begin{array}{c}\text { Diameter } \\
\text { min } \\
(\mathrm{mm})\end{array}$ & $\begin{array}{c}\text { Diameter } \\
\text { rencana } \\
(\mathrm{mm})\end{array}$ & $\begin{array}{c}\text { Diameter } \\
\text { pakai } \\
\text { (inch) }\end{array}$ \\
\hline Air kotor & & & & \\
Lt. 2- Lt. 1 & 8 & 50 & 100 & 4 \\
Lt.1-Lobby & 16 & 50 & 100 & 4 \\
Lobby-G.01 & 138 & 100 & 100 & 4 \\
G.01-G.02 & 138 & 100 & 100 & 4 \\
G. 02 & 178 & 100 & 100 & 4 \\
Air bersih & & & & \\
Lt. 2- Lt. 1 & 6 & 50 & 100 & 4 \\
Lt.1-Lobby & 12 & 50 & 100 & 4 \\
Lobby-G.01 & 98 & 100 & 100 & 4 \\
G.01-G.02 & 106 & 100 & 100 & 4 \\
G. 02 & 164 & 100 & 100 & 4 \\
\hline
\end{tabular}

\subsection{Penentuan Diameter Pipa Ven}

Besar kecilnya diameter Pipa Ven ditentukan oleh banyaknya unit alat plambing dan diameter pipa tegak air buangan. Contoh penentuan diameter pipa ven untuk kloset dengan UBAP 4 berdiameter $75 \mathrm{~mm}$, disesuaikan dengan Tabel ukuran pipa tegak dan pipa cabang ven pada SNI 8153 tahun 2015 didapatkan nilai diameter $40 \mathrm{~mm}$. Diameter untuk pipa ven tertera pada Table 5 dibawah ini: 
Tabel 5. Diameter Pipa Ven

\begin{tabular}{lcccc}
\hline $\begin{array}{c}\text { Alat } \\
\text { Plambing }\end{array}$ & UBAP & $\begin{array}{c}\text { Diameter } \\
\text { min } \\
(\mathrm{mm})\end{array}$ & $\begin{array}{c}\text { Diameter } \\
\text { rencana } \\
(\mathrm{mm})\end{array}$ & $\begin{array}{c}\text { Diameter } \\
\text { pakai } \\
\text { (inch) }\end{array}$ \\
\hline $\begin{array}{l}\text { Air kotor } \\
\text { Kloset } \\
\text { Air bersih }\end{array}$ & 4 & 75 & 40 & 1.5 \\
$\begin{array}{l}\text { Pengering } \\
\text { Lantai }\end{array}$ & 2 & 40 & 40 & 1.5 \\
Lavatori & 1 & 32 & 32 & 1 \\
Bak Mandi & 2 & 40 & 40 & 1.5 \\
\hline
\end{tabular}

\subsection{Perencanaan Sistem Pemadam Kebakaran}

Sistem pemadam kebakaran pada Hotel Pesona Alam direncanakan menggunakan 2 model sistem, yaitu sistem di luar gedung dan juga sistem di dalam gedung. Sistem di dalam gedung berupa pemasangan fire hose reel dan sprinkle di setiap lantai. Sedangkan sistem luar gedung berupa pemasangan 3 buah pillar hydrant.

\subsection{Penentuan Kebutuhan Air dan Kapasitas Ground Water Tank (GWT)}

\subsubsection{Pillar Hydrant}

Kebutuhan air untuk pillar hydrant didapatkan dari penjumlahan debit masingmasing pillar hydrant yang akan dipasang. Hasil perhitungan debit total pillar hydrant adalah:

$$
\begin{aligned}
\text { Qpillar Hydrant } & 38 \mathrm{l} / \mathrm{det}+19 \mathrm{l} / \mathrm{det}+201 / \mathrm{det} \\
& =77 \mathrm{l} / \mathrm{det}
\end{aligned}
$$

Asumsi waktu air simpanan sebesar 45 menit, maka dihasilkan Volume air sebesar:

$$
\begin{aligned}
\mathrm{V}_{\text {pillar Hydrant }} & =771 / \text { det } \times 45 \text { menit } \\
& =207900 \text { liter } \\
& =207.9 \mathrm{~m}^{3}
\end{aligned}
$$

\subsubsection{Fire Hose Reel}

Asumsi digunakan 2 fire hose reel ketika kebakaran berlangsung, diketahui debit 1 fire hose reel adalah 400 1/menit, sehingga:

$$
\begin{aligned}
Q_{\text {firehose reel }} & =2 \times 4001 / \text { menit } \\
& =8001 / \text { menit }
\end{aligned}
$$

Setelah debit total didapatkan, dengan asumsi waktu air simpanan 45 menit, Volume dapat diketahui:

$$
\begin{aligned}
\mathrm{V}_{\text {fire hose reel }} & =8001 / \text { menit } \times 45 \text { menit } \\
& =36000 \text { liter } \\
& =36 \mathrm{~m}^{3}
\end{aligned}
$$

\subsubsection{Sprinkler}

Diketahui debit air pada 1 kepala Sprinkler adalah 225 1/menit, asumsi digunakan 2 sprinkler saat kebakaran berlangsung, sehingga didapatkan debit sebesar:

$$
\begin{aligned}
\mathrm{Q}_{\text {sprinkler }} & =2 \times 225 \mathrm{l} / \mathrm{menit} \\
& =450 \mathrm{l} / \mathrm{menit}
\end{aligned}
$$

Maka volume yang dihasilkan sebesar:

$$
\begin{aligned}
\mathrm{V}_{\text {sprinkle }} & =4501 / \text { menit } \times 45 \text { menit } \\
& =20250 \text { liter } \\
& =20.25 \mathrm{~m}^{3}
\end{aligned}
$$

Kebutuhan air bersih total adalah: 


$$
\begin{aligned}
V_{\text {total }} & =207.9 \mathrm{~m}^{3}+36 \mathrm{~m}^{3}+20.25 \mathrm{~m}^{3} \\
& =264.15 \mathrm{~m}^{3} \approx 270 \mathrm{~m}^{3}
\end{aligned}
$$

Maka dimensi ground reservoir yang digunakan sebesar: $10 \mathrm{~m} \times 7 \mathrm{~m} \times 4 \mathrm{~m}$, maka kapasitas efektif sebesar $280 \mathrm{~m}^{3}$.

\subsection{Perhitungan sistem perpipaan hidran kebakaran}

\subsubsection{Pipa pembagi utama}

1. Debit $=850 \quad 1 /$ menit $=0.014$ $\mathrm{m}^{3} /$ detik

2. Diameter $=\sqrt{\frac{4(0,014)}{\Pi(2)}}$

$$
=0.095 \mathrm{~m}=95 \mathrm{~mm}
$$

3. Dipakai $\mathrm{D}=100 \mathrm{~mm}=0.1 \mathrm{~m}$

4. $\mathrm{V}_{\mathrm{cek}}=\frac{4(0,014)}{\Pi(0,1)^{2}}$

$$
=1.8 \mathrm{~m} / \mathrm{det}
$$

Diameter $100 \mathrm{~mm}$ dapat digunakan.

\subsubsection{Pipa Pembagi}

1. Debit $=425 \mathrm{l} / \mathrm{menit}=0.007$ $\mathrm{m}^{3} /$ detik

2. Diameter $=\sqrt{\frac{4(0,007)}{\Pi(2)}}$

$$
=0.067 \mathrm{~m}=67 \mathrm{~mm}
$$

3. Dipakai $\mathrm{D}=80 \mathrm{~mm}=0.08 \mathrm{~m}$

4. $\mathrm{V}_{\text {cek }}=\frac{4(0,007)}{\Pi(0,08)^{2}}=1.41 \mathrm{~m} / \mathrm{det}$

\subsubsection{Pipa Cabang}

1. Debit $=142 \mathrm{l} / \mathrm{menit}=0.0024$ $\mathrm{m}^{3} /$ detik

2. Diameter $=\sqrt{\frac{4(0,0024)}{\Pi(2)}}=39 \mathrm{~mm}$

3. Digunakan $\mathrm{d}=40 \mathrm{~mm}=0.04 \mathrm{~m}$
4. $\mathrm{V}_{\mathrm{cek}}=\frac{4(0,0024)}{\Pi(0,04)^{2}}=1.88 \mathrm{~m} / \mathrm{det}$ $(0.9 \mathrm{~m} / \mathrm{det}<\mathrm{V}<2 \mathrm{~m} / \mathrm{det})$

Diameter $40 \mathrm{~mm}$ dapat digunakan. Berdasarkan SNI 03-3989-2000, jumlah maksimum kepala sprinkler untuk ukuran pipa $25 \mathrm{~mm}$ adalah 3 buah. Selebihnya dipergunakan ukuran yang lebih besar. Jumlah Sprinkler perlantai dapat dilihat pada Tabel 6.

Tabel 6. Jumlah Sprinkler Tiap lantai

\begin{tabular}{lc}
\hline \multicolumn{1}{c}{ Lantai } & $\begin{array}{c}\text { Jumlah } \\
\text { sprinkler }\end{array}$ \\
\hline Ground 1 & 104 \\
Ground 2 & 168 \\
Lobby & 162 \\
Lantai 1 & 158 \\
Lantai 2 & 154 \\
Total & 874 \\
\hline
\end{tabular}

\section{SIMPULAN DAN SARAN}

\subsection{Simpulan}

1. Kebutuhan air bersih perhari pada Hotel Pesona alam adalah $230 \mathrm{~m}^{3} /$ hari. Dimensi ground water tank yang digunakan adalah $8 \mathrm{~m} \times 5 \mathrm{~m} \times 2 \mathrm{~m}$. sedangkan dimensi roof tank yang digunakan adalah $5 \mathrm{~m} \times$ $3 \mathrm{~m} \times 1 \mathrm{~m}$. Diameter Pipa Distribusi yang digunakan adalah $15 \mathrm{~mm}$ (0.5”) untuk keran cuci tangan, pancuran mandi dan bath tub, dan $20 \mathrm{~mm}$ $(0.75 ")$ untuk kloset dan urinoir. Sedangkan untuk pipa tegak 
perkamar digunakan diameter minimum $32 \mathrm{~mm}$ (1.25").

2. Dimensi Pipa air buangan yang digunakan untuk air kotor adalah 75 mm (3") untuk kloset dan $100 \mathrm{~mm}$ (4”) untuk pipa tegak. Sedangkan diameter pipa air bekas yang digunakan adalah 100 mm (4") untuk pipa tegak, $32 \mathrm{~mm}$ (1.25”) untuk washtafel, dan $40 \mathrm{~mm}$ (1.5”) untuk floor drain.

3. Sistem pemadam kebakaran pada Hotel Pesona Alam menggunakan 3 jenis Hidran kebakaran yaitu 3 buah pillar hydrant untuk luar Gedung, fire hose reel, dan sprinkler sebanyak 874 titik untuk proteksi dalam Gedung. Berdasarkan perhitungan volume, didapatkan kebutuhan air bersih sebesar $270 \mathrm{~m}^{3}$ untuk sistem pemadaman kebakaran.

\subsection{Saran}

Pada penelitian selanjutnya, diperlukan perencanaan rencana anggaran biaya (RAB) yang sesuai dengan kebutuhan pipa.

\section{DAFTAR PUSTAKA}

Affandi, J., Pharmawatu, K., \& Nurprabowo, A. (2016). Perencanaan Sistem Instalasi Plambing Air Bersih Gedung Hotel Tebu. Jurnal Rekayasa Lingkungan Institut Teknologi Nasional, 4(2), 19.

Anonim. (2000a). SNI 03-1745-2000: Tata cara perencanaan dan pemasangan system pipa tegak dan slang untuk pencegahan bahaya kebakaran pada bangunan rumah dan gedung. Jakarta: Badan Standarisasi Nasional.

Anonim. (2000b). SNI 03-3989-2000: Tata cara perencanaan dan pemasangan sistem sprinkler otomatik untuk pencegahan bahaya kebakaran pada bangunan gedung. Jakarta: Badan Standarisasi Nasional.

Anonim. (2000c). SNI 03-6481-2000: Sistem Plambing. Jakarta: Badan Standarisasi Nasional.

Anonim. (2005).SNI 03-7065-2005: Tata Cara Perencaaan Sistem Plambing. Jakarta: Badan Standarisasi Nasional.

Anonim. (2015). SNI 8153-2015: Sistem Plambing pada Bangunan Gedung. Jakarta: Badan Standarisasi Nasional.

Artayana, K. C. B., \& Atmaja, G. I. (2010). Perencanaan Instalasi Air Bersih dan Air Kotor pada Bangunan Gedung dengan Menggunakan Sistem Pompa. Jurnal Ilmiah Teknik Mesin Universitas Udayana, 4(1), 51-56.

Aurumbinang, E. I. (2018). Perencanaan Perpipaan Air Bersih Dan Air Buangan Pada Proyek Pembangunan Meotel Jember. 
Mahardika, P. (2018). Evaluasi Instalasi Plumbing Air Bersih Rumah Tipe 42 Menggunakan Pipe Flow Expert Berdasarkan SNI 03-4065-2005 dan BS 6700. Jurnal Teknologi Terapan, 4(1), 1-6.

Noerbambang, S. M., \& Morimura, T. (1993). Perencanaan dan Pemeliharaan Sistem Plambing. Jakarta: PT. Pradnya Paramita. 